\title{
Force to Shear the Stalk, Stalk Diameter, and Yield of Broccoli in Response to Nitrogen Fertilization and Within-row Spacing
}

\author{
Brian A. Kahn', Phillip G. Shilling' ${ }^{2}$ Gerald H. Brusewitz ${ }^{3}$, and Ronald W. McNew ${ }^{4}$ \\ Oklahoma State University, Stillwater, OK 74078
}

Additional index words. Brassica oleracea (Italica Group), fertilizer, plant population, quality, stalk texture

\begin{abstract}
Broccoli [Brassica oleracea L. (Italica Group)] crops may be rejected by wholesale buyers due to unacceptably tough stalks. Four experiments were conducted to examine the effects of various $\mathbf{N}$ levels and two withinrow spacings (15 and $30 \mathrm{~cm})$ on force to shear the stalk, stalk diameter, and yield of transplanted 'Premium Crop' broccoli. Shear was not affected by within-row spacing, and average stalk diameter was decreased only $3 \mathrm{~mm}$ by reducing spacing from 30 to $15 \mathrm{~cm}$. Although the $15-\mathrm{cm}$ spacing sometimes produced the greatest total number of marketable, heads, this spacing resulted in higher cull head production, lower average marketable head weight, delayed maturity, and a lower percentage of field-planted transplants producing marketable heads than the 30-cm spacing. Increasing $\mathbf{N}$ fertilization decreased force to shear the stalk in only one experiment, when plants were exposed to water deficits and high temperatures. Nitrogen affected stalk diameter only when very low rates $\left(37\right.$ and $\left.74 \mathrm{~kg} \cdot \mathrm{ha}{ }^{-1}\right)$ were included. Yield of marketable-quality heads often showed no significant response to rates of applied $\mathrm{N}>112$ $\mathrm{kg} \cdot \mathrm{ha}^{-1}$, particularly at the $30-\mathrm{cm}$ spacing. Hollow stem was negligible in all experiments.
\end{abstract}

The area devoted to broccoli production in the United States more than doubled between 1972 and 1985 (U.S. Dept. Agr., 1987). As broccoli production expanded into nontraditional areas, such as the southcentral United States, wholesale buyers sometimes encountered defects in crops produced by inexperienced growers. One specific complaint involved tough, fibrous stalks. In some cases, stalk toughness was thought to be related to large stalk diameters. Growers intuitively sought to overcome these problems by increasing $\mathrm{N}$ fertilization and decreasing plant spacings, but were not always successful.

The literature contains several studies on plant spacings (Cutcliffe, 1975a; Palevitch, 1970; Zink and Akana, 1951), rates of applied N (Beverly et al., 1986; Cutcliffe et al., 1968; Greenwood et al., 1980; Kowalenko and Hall, 1987), or N and spacing combinations (Cutcliffe, 1971; Dufault and Waters, 1985) for maximization of broccoli yield. However, research into quality aspects of broccoli has focused primarily on hollow stem (Cutcliffe, 1972, 1975b; Hipp, 1974). Other quality aspects, particularly stalk toughness, require no attention.

The objectives of this study were to determine the effects of $\mathrm{N}$ rate and within-row spacing on force to shear the stalk and stalk diameter of broccoli, and to identify combinations of $\mathrm{N}$ and within-row spacing that would maximize yield of marketable-quality heads.

Received for publication 7 May 1990. Journal Article no. J-5781 of the Agr. Expt. Sta., Oklahoma State Univ., Stillwater. We gratefully acknowledge the donation of transplants by Speedling, Inc., Sun City, Fla. The information given in this publication is for educational purposes only. Mention of a trademark, proprietary product, or vendor does not constitute a guarantee or warranty of the product, nor does it imply approval or disapproval to the exclusion of other products or vendors that may also be available. The cost of publishing this paper was defrayed in part by the payment of page charges. Under postal regulations, this paper therefore must be hereby marked advertisement solely to indicate this fact.

'Associate Professor, Dept. of Horticulture and Landscape Architecture.

${ }^{2}$ Former Graduate Assistant. Present address: Dept. of Horticulture and Forestry, Univ. of Arkansas, Fayetteville, AR 72701.

${ }^{3}$ Professor, Dept. of Agricultural Engineering.

${ }^{4}$ Professor. Present address: Agricultural Statistics Laboratory, Univ. of Arkansas, Fayetteville, AR 72701.

\section{Materials and Methods}

The experiments were conducted at the Vegetable Research Station, Bixby, Okla., on a Severn very fine sandy loam [coarsesilty, mixed (calcareous), thermic Typic Udifluvents]. Soil tests were conducted before each experiment. Soil nitrate N was determined with $\mathrm{CaSO}_{4}$ extraction, while available soil $\mathrm{P}$ and $\mathrm{K}$ were determined with Mehlich III extractions (McElreath and Johnson, 1990). A preplant-incorporated application of 2,6-dinitro-N,N-dipropyl-4-(trifluoromethyl)benzenamine (trifluralin) at $560 \mathrm{~g} \cdot \mathrm{ha}^{-1}$ was made before each experiment to control weeds. Standard commercial foliar insecticides were applied as required. Sprinkler irrigation was provided based on subjective soil observations. Plots received $\approx 8$ to $13 \mathrm{~mm}$ of water per application.

A split-plot design was used. Nitrogen rates were assigned to main plots and arranged as a $4 \times 4$ Latin square, while withinrow spacings were assigned to subplots. Double-row plots (hereafter called "units") $2.5 \mathrm{~m}$ long were used, with $30 \mathrm{~cm}$ between the two rows in each unit and $90 \mathrm{~cm}$ between centers of the units. Each $\mathrm{N}$ main plot contained six double-row units, with the second and fifth units used for data. Buffers of $4 \mathrm{~m}$ were maintained on all sides of each main plot to guard against $\mathrm{N}$ movement between plots. Nitrogen rates were planned to be 56, 112, 168, and $224 \mathrm{~kg} \cdot \mathrm{ha}^{-1}$ in Fall 1986 and 112, 168, 224, and $280 \mathrm{~kg} \cdot \mathrm{ha}^{-1}$ thereafter. These rates were to be achieved by combining three equally divided sidedressings of urea: one at planting, a second $2-1 / 2$ weeks after planting, and a third 5 weeks after planting. The actual $\mathrm{N}$ rates used and the dates of $\mathrm{N}$ fertilization are shown in Table 1.

Plug-type transplants of 'Premium Crop' broccoli, with a rooting medium volume of $\approx 18 \mathrm{~cm}^{3} /$ plug, were set at withinrow spacings of 15 or $30 \mathrm{~cm}$. The resulting populations were 14.8 or 7.4 plants $/ \mathrm{m}^{2}$, respectively. Each transplant received $\approx 200 \mathrm{ml}$ of starter solution at planting. The starter solution for the $30-\mathrm{cm}$ spacing provided $719 \mathrm{~N}-316 \mathrm{P}-597 \mathrm{~K}\left(\mathrm{mg} \cdot\right.$ liter $\left.^{-1}\right)$, respectively, plus O,O-diethyl O-[6-methyl-2-(1-methylethyl)-4pyrimidinyl] phosphorothioate (diazinon) at $253 \mathrm{mg} \cdot$ liter $^{-1}$. Halfstrength starter solution was used for the $15-\mathrm{cm}$ spacing to ensure equivalent rates of fertilizer and diazinon per unit area. Planting dates are shown in Table 1.

Petiole samples were taken shortly before heading from three 
Table 1. Dates of $\mathrm{N}$ fertilization, rates of applied $\mathrm{N}$, and planting dates for four experiments with broccoli.

\begin{tabular}{|c|c|c|c|c|}
\hline $\mathrm{N}$ application dates & \multicolumn{4}{|c|}{$\mathrm{N}$ applied $\left(\mathrm{kg} \cdot \mathrm{ha}^{-1}\right)$} \\
\hline 20 Aug. 1986 (at planting) & 18 & 36 & 56 & 74 \\
\hline 10 Sept. 1986 (sidedress) & 19 & 38 & 56. & 75 \\
\hline Treatment totals, Fall 1986 & 37 & 74 & 112 & 149 \\
\hline 13 Feb. 1987 (preplant) & \multicolumn{4}{|c|}{58 (entire trial area) } \\
\hline 20 Mar. 1987 (at planting) & 18 & 36 & 54 & 74 \\
\hline 7 Apr. 1987 (sidedress) & 18 & 37 & 56 & 74 \\
\hline 24 Apr. 1987 (sidedress) & 18 & 37 & 56 & 74 \\
\hline Treatment totals, Spring 1987 & 112 & 168 & 224 & 280 \\
\hline Residual N (soil test) ${ }^{z}$ & \multicolumn{4}{|c|}{39 (entire trial area) } \\
\hline 6 Aug. 1987 (preplant) & \multicolumn{4}{|c|}{58 (entire trial area) } \\
\hline 18 Aug. 1987 (at planting) & 0 & 23 & 41 & 61 \\
\hline 4 Sept. 1987 (sidedress) & 0 & 24 & 43 & 61 \\
\hline Treatment totals, Fall 1987 & 97 & 144 & 181 & 219 \\
\hline 24 Feb. 1988 (preplant) & \multicolumn{4}{|c|}{60 (entire trial area) } \\
\hline 23 Mar. 1988 (at planting) & 18 & 36 & 54 & 74 \\
\hline 11 Apr. 1988 (sidedress) & 17 & 36 & 55 & 73 \\
\hline 26 Apr. 1988 (sidedress) & 17 & 36 & 55 & 73 \\
\hline Treatment totals, Spring 1988 & 112 & 168 & 224 & 280 \\
\hline
\end{tabular}

${ }^{7}$ Residual soil $\mathrm{N}$ was negligible in the other three experiments.

plants per data unit to measure $\mathrm{N}$ concentration. The first visibly expanded leaf at the apex was noted on each plant; then, proceeding basipetally, the sixth leaf was identified and severed from the plant. Leaf blades were stripped from the petioles. Petioles were dried at 70C, ground to pass a 20 -mesh screen, analyzed for $\mathrm{N}$ using the macro-Kjeldahl method without nitrate reduction (Assn. of Official Analytical Chemists, 1970), and $\mathrm{N}$ concentrations calculated.

At harvest, plants were cut near the base and leaves were removed. Heads were placed against a vertical surface and stalks were trimmed at $20.5 \mathrm{~cm}$ from the top of the dome. Heads then were weighed, measured for stalk diameter at the newly cut end (butt), and classified as "marketable" or "cull". Cull numbers reported thus were based on heads maturing during the harvest periods and did not include cull heads remaining in the field after harvest periods were completed. Reasons for culling were hollow stems; yellow or senescent flower buds; uneven domes (due to unequal flower stalk lengths or extreme differences in bud sizes); or a fresh weight of $<80 \mathrm{~g}$, which was considered to indicate a "button-like" head. Marketable heads were placed in perforated plastic bags and held at 5C.

The maximum force to shear the stalk was measured within $24 \mathrm{hr}$ of harvest. Heads again were placed against a vertical surface and stalks were marked at 17 and $15 \mathrm{~cm}$ from the top of the dome. Stalks then were sheared, first at $17 \mathrm{~cm}$ and then at $15 \mathrm{~cm}$, using an Instron Universal Testing Machine (Instron Corp., Canton, Mass.) equipped with a 500-kg reversible load cell (Assembly A217-17) and a single-blade shear cell $3.2 \mathrm{~mm}$ thick. The crosshead speed was $2.0 \mathrm{~cm} \cdot \mathrm{min}^{-1}$, with a chart speed of $2.5 \mathrm{~cm} \cdot \mathrm{min}^{-1}$; full scale on the chart was $50 \mathrm{~kg}$. The two readings per stalk were averaged before statistical analysis.

The percentage of field-planted transplants producing marketable heads was calculated by dividing the number of marketable heads per plot by the total number of potential data plants in that plot. The initial stands after transplanting (12 or 24 data plants at the 30 - or $15-\mathrm{cm}$ spacings, respectively) were used as the numbers of potential data plants.

Fall 1986. A preplant soil test indicated 5.6N( $\left.\mathrm{NO}_{3}\right)-147 \mathrm{P}$ -
292K $\left(\mathrm{kg} \cdot \mathrm{ha}^{-1}\right)$. No preplant fertilization was used. Rainfall during the experimental period totaled $\approx 470 \mathrm{~mm}$. Plots were sprinkler-irrigated on 20, 21, 22, and 25 Aug. In late September, a century flood occurred $(250 \mathrm{~mm}$ of rain in 3 consecutive days) that prevented application of the sidedressing scheduled for 5 weeks after planting, caused the loss of one replication, and delayed plant sampling for $\mathrm{N}$ concentration until 3 Nov. (during harvest). However, the experiment was continued to determine whether the stresses imposed would result in production of tough stalks. Seven harvests were made between 20 Oct. and 10 Nov. as central heads matured. Side shoots were not harvested in this or later experiments.

Spring 1987. A preplant soil test indicated 4.5N(NO$\left.)_{3}\right)-180 \mathrm{P}-$ $296 \mathrm{~K}\left(\mathrm{~kg} \cdot \mathrm{ha}^{-1}\right)$. Soil was prepared with a broadcast, preplantincorporated application of $58 \mathrm{~N}-26 \mathrm{P}-48 \mathrm{~K}\left(\mathrm{~kg} \cdot \mathrm{ha}^{-1}\right)$. Rainfall during the experimental period totaled $\approx 150 \mathrm{~mm}$. Plots were sprinkler-irrigated on 13, 18, and 21 May. Plants were sampled for $\mathrm{N}$ concentration on 7 May. Six harvests were made between 19 May and 4 June as central heads matured.

Fall 1987. A preplant soil test indicated 39N( $\left.\mathrm{NO}_{3}\right)-172 \mathrm{P}-$ $371 \mathrm{~K}\left(\mathrm{~kg} \cdot \mathrm{ha}^{-1}\right)$. Soil test results were delayed, so the soil was prepared with a broadcast, preplant-incorporated application of $58 \mathrm{~N}-26 \mathrm{P}-48 \mathrm{~K}$ (kg.ha1). When the unexpectedly high residual soil $\mathrm{N}$ was discovered, sidedressing rates were adjusted accordingly. However, plant growth was so vigorous that the canopy closed before the sidedressing scheduled for 5 weeks after planting could be applied. Rainfall during the experimental period totaled $190 \mathrm{~mm}$. Plots were sprinkler-irrigated on 19 and 24 Aug. and on 9 Oct. Plants were sampled for $\mathrm{N}$ concentration on 2 Oct. Six harvests were made between 15 Oct. and 2 Nov. as central heads matured.

Spring 1988. A preplant soil test indicated $4.5 \mathrm{~N}\left(\mathrm{NO}_{3}\right)-112 \mathrm{P}-$ $265 \mathrm{~K}\left(\mathrm{~kg} \cdot \mathrm{ha}^{-1}\right)$. Soil was prepared with a broadcast, preplantincorporated application of $60 \mathrm{~N}-27 \mathrm{P}-50 \mathrm{~K}\left(\mathrm{~kg} \cdot \mathrm{ha}^{-1}\right)$. Rainfall during the experimental period totaled $\approx 90 \mathrm{~mm}$. Plots were sprinkler-irrigated on 5, 10, 16, and 30 May and on 2 June. Plants were sampled for $\mathrm{N}$ concentration on 12 May. Four harvests were made between 23 May and 3 June as central heads matured.

Data from each experiment were subjected to analysis of variance procedures. Main effects of $\mathrm{N}$ were partitioned into linear, quadratic, and cubic components using single-degree-of-freedom contrasts. The $\mathrm{N} \times$ spacing interaction term also was partitioned into $\mathrm{N}$-linear $\times$ spacing, $\mathrm{N}$-quadratic $\times$ spacing, and $\mathrm{N}$-cubic $\times$ spacing components.

\section{Results and Discussion}

Petiole $N$ concentration. Applied $\mathrm{N}$ in the fall experiments ranged from 37 to $219 \mathrm{~kg} \cdot \mathrm{ha}^{-1}$. Within this range, petiole $\mathrm{N}$ concentration increased linearly with applied $\mathrm{N}$, and there was no effect of spacing (Table 2). The combination of a late sampling date and $\mathrm{N}$ losses due to flooding-induced leaching contributed to the relatively low $\mathrm{N}$ concentrations in Fall 1986.

Applied $\mathrm{N}$ in the spring experiments ranged from 112 to 280 $\mathrm{kg} \cdot \mathrm{ha}^{-1}$ Within this range, petiole $\mathrm{N}$ concentration increased quadratically with applied N (Table 2). Letey et al. (1983) found that the ratio of broccoli plant $\mathrm{N}$ concentration to applied $\mathrm{N}$ decreased as $\mathrm{N}$ applications increased from 90 to $270 \mathrm{~kg} \cdot \mathrm{ha}^{-1}$ on a sandy loam (Typic Xerofluvent). Petiole N concentrations were higher at the $30-\mathrm{cm}$ than at the $15-\mathrm{cm}$ spacing in the spring (Table 2). The stress of increasing temperatures on the maturing spring broccoli crops may have intensified interplant competition for $\mathrm{N}$. 
Table 2. Petiole $\mathrm{N}$ concentration of broccoli in response to applied $\mathrm{N}$ and within-row spacing.

\begin{tabular}{|c|c|c|c|c|c|c|c|c|}
\hline \multirow{3}{*}{$\begin{array}{l}\text { Within-row } \\
\text { spacing } \\
(\mathrm{cm})\end{array}$} & \multicolumn{4}{|c|}{$\begin{array}{c}\text { N rates } \\
\left(\mathrm{kg} \cdot \mathrm{ha}^{-1}\right)\end{array}$} & \multicolumn{4}{|c|}{$\begin{array}{l}\text { Petiole N } \\
\text { concn }(\%)\end{array}$} \\
\hline & \multicolumn{4}{|c|}{ Season $^{\mathrm{z}}$} & \multicolumn{4}{|c|}{ Season } \\
\hline & F86 & F87 & $\$ 87$ & S88 & F86 & F87 & $\mathrm{S} 87$ & S88 \\
\hline 15 & 37 & 97 & 112 & 112 & 0.5 & 2.6 & 1.9 & 1.6 \\
\hline 15 & 74 & 144 & 168 & 168 & 0. & 3.2 & 2. & 2 \\
\hline 15 & 112 & 181 & 224 & 224 & 0.8 & 3.1 & 2.6 & 2. \\
\hline 15 & 149 & 219 & 280 & 280 & 0.8 & 3.3 & 2.6 & 2.7 \\
\hline 30 & 37 & 97 & 112 & 112 & 0.6 & 2.2 & 2.6 & 2.0 \\
\hline 30 & 74 & 144 & 168 & 168 & 0.6 & 3.3 & 2.8 & 2. \\
\hline 30 & 112 & 181 & 224 & 224 & 0.9 & 3.5 & 3.0 & 3.0 \\
\hline 30 & 149 & 219 & 280 & 280 & 0.9 & 3.7 & 3.0 & 2.7 \\
\hline \multicolumn{9}{|l|}{ Main effects ${ }^{y}$} \\
\hline Nitrogen ${ }^{x}$ & & & & & $\mathrm{~L}^{* *}$ & $\mathrm{~L}^{*}$ & $\mathrm{Q}^{*}$ & $\mathrm{Q}^{*}$ \\
\hline Spacing & & & & & NS & NS & $* *$ & $*$ \\
\hline
\end{tabular}

${ }^{2} \mathrm{~F} 86$ = Fall 1986; F87 = Fall 1987; S87 = Spring 1987; S88 = Spring 1988.

${ }^{y}$ All $\mathrm{N} \times$ spacing interactions were nonsignificant at $P=0.05$.

${ }^{\mathrm{x}} \mathrm{L}=$ Linear; $\mathrm{Q}=$ Quadratic.

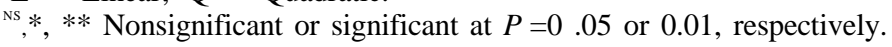

Quality aspects and yield. Within-row spacing had no effect on maximum force to shear the stalk in any experiment (Table 3). Increasing $\mathrm{N}$ fertilization decreased shear force only in Spring 1988, when heads were developing under unusually warm and dry conditions (Table 3 ). The average air temperature for 1 May through 3 June 1988 was 19C, and there were 15 days when air maxima exceeded $26 \mathrm{C}$. The total rainfall during this same 34 days was only $20 \mathrm{~mm}$, of which $14 \mathrm{~mm}$ fell on 22 May. Wilted plants were noted on two occasions in 1988, despite periodic irrigation.

Environmental stresses may be conducive to relatively high shear force values, as evidenced by the flood-affected Fall 1986 experiment (Table 3). However, applied $\mathrm{N}$ had no effect on shear force in 1986, even though petiole $\mathrm{N}$ concentrations in- creased with added N (Table 2). Massey et al. (1962) found that the average dry matter of broccoli central heads was $10.9 \%$ in irrigated plots vs. $14.4 \%$ in unirrigated plots, and crude fiber was positively correlated $(P=0.05)$ with percent dry matter in 2 years. Kowalenko and Hall (1987) reported that the percent dry matter in broccoli heads from unirrigated plots was decreased as N rates increased in 1979 (a dry year) but was not affected in 1982 (a wetter year). We did not measure percent dry matter or crude fiber. However, a possible explanation for the $\mathrm{N}$ effect on force to shear the stalk in Spring 1988 would be that dry matter and fiber contents were decreased as $\mathrm{N}$ rates increased.

Pearson correlation coefficients were calculated for petiole N concentration with maximum force to shear the stalk. No strong, significant $(P=0.01)$ correlations were found in any experiment (correlations not presented).

Average marketable head stalk diameters were smaller at the $15-\mathrm{cm}$ than at the $30-\mathrm{cm}$ spacing in all experiments (Table 3). Nitrogen had no effect on stalk diameter except in Fall 1986, when the lowest rates of applied $\mathrm{N}$ were used, and when diameter tended to increase as $\mathrm{N}$ rate was increased (Table 3). Increased plant density resulted in decreased stalk diameters in several other studies (Aldrich et al., 1961; Chung, 1982; Thompson and Taylor, 1976; Zink and Akana, 1951).

The number of cull heads per hectare was consistently higher at the $15-\mathrm{cm}$ than at the 30-cm spacing (Table 3). Increased cull head production at high plant populations also was noted by Zink and Akana (1951) and by Cutcliffe (1971). At close withinrow spacings $(10$ or $15 \mathrm{~cm})$, there is a tendency for the more vigorous plants to shade the weaker ones, leading to production of many cull heads (Zink and Akana, 1951),

Nitrogen had no effect on cull head production in three out of four experiments (Table 3). In Fall 1986, increasing $\mathrm{N}$ resulted in fewer cull heads, especially at the $15-\mathrm{cm}$ spacing; the $\mathrm{N}$-linear $\times$ spacing interaction was significant (Table 3). Dufault and Waters (1985) reported linear decreases in cull yield per hectare as $\mathrm{N}$ rates increased from 56 to $224 \mathrm{~kg} \cdot \mathrm{ha}^{-1}$.

Cull weights per hectare followed the same trends as cull

Table 3. Quality characteristics of broccoli in response to applied $\mathrm{N}$ and within-row spacing.

\begin{tabular}{|c|c|c|c|c|c|c|c|c|c|c|c|c|c|c|c|c|}
\hline \multirow{4}{*}{$\begin{array}{l}\text { Within-row } \\
\text { spacing } \\
\text { (cm) }\end{array}$} & \multirow{2}{*}{\multicolumn{4}{|c|}{$\begin{array}{c}\mathrm{N} \text { rates } \\
\left(\mathrm{kg} \cdot h a^{-1}\right)\end{array}$}} & \multicolumn{8}{|c|}{ Marketable heads } & & & & \\
\hline & & & & & \multicolumn{4}{|c|}{$\begin{array}{l}\text { Max. stalk shear force } \\
(\mathrm{N})\end{array}$} & \multicolumn{4}{|c|}{$\begin{array}{l}\text { Avg. stalk diam } \\
(\mathrm{mm})\end{array}$} & \multicolumn{4}{|c|}{$\begin{array}{c}\text { Cull heads } \\
\text { (thousands/ha) }\end{array}$} \\
\hline & \multicolumn{4}{|c|}{ Season $^{2}$} & \multicolumn{4}{|c|}{ Season } & \multicolumn{4}{|c|}{ Season } & \multicolumn{4}{|c|}{ Season } \\
\hline & F86 & F87 & $\mathrm{S} 87$ & $\mathrm{~S} 88$ & F86 & $\mathrm{F} 87$ & S87 & $\mathrm{S} 88$ & F86 & F87 & S87 & $\mathrm{S} 88$ & F86 & F87 & S87 & S88 \\
\hline$\overline{15}$ & 37 & 97 & 112 & 112 & 216 & 157 & 167 & 176 & 29 & 29 & 28 & 29 & 68 & 22 & 66 & 12 \\
\hline 15 & 74 & 144 & 168 & 168 & 225 & 147 & 157 & 157 & 28 & 29 & 28 & 28 & 49 & 20 & 60 & 22 \\
\hline 15 & 112 & 181 & 224 & 224 & 216 & 147 & 147 & 157 & 29 & 29 & 31 & 28 & 23 & 15 & 62 & 17 \\
\hline 15 & 149 & 219 & 280 & 280 & 216 & 157 & 137 & 167 & 30 & 28 & 28 & 29 & 10 & 8 & 65 & 14 \\
\hline 30 & 37 & 97 & 112 & 112 & 225 & 157 & 157 & 186 & 29 & 32 & 32 & 31 & 23 & 5 & 32 & 11 \\
\hline 30 & 74 & 144 & 168 & 168 & 225 & 157 & 157 & 167 & 31 & 31 & 31 & 33 & 10 & 6 & 23 & 8 \\
\hline 30 & 112 & 181 & 224 & 224 & 225 & 157 & 147 & 167 & 32 & 33 & 32 & 32 & 12 & 2 & 22 & 9 \\
\hline \multirow{2}{*}{\multicolumn{17}{|c|}{ Main effects ${ }^{y}$}} \\
\hline & & & & & & & & & & & & & & & & \\
\hline Nitrogen $x$ & & & & & NS & NS & NS & $\mathrm{L}^{* *}$ & $\mathrm{~L}^{*}$ & NS & NS & NS & w & NS & NS & NS \\
\hline Spacing & & & & & NS & NS & NS & NS & $*$ & *** & ** & $* *$ & $\mathrm{w}$ & $* *$ & ** & $* *$ \\
\hline
\end{tabular}

${ }^{2}$ F86 $=$ Fall 1986; F87 = Fall 1987; S87 = Spring 1987; S88 = Spring 1988.

${ }^{y}$ All $\mathrm{N} \times$ spacing interactions were nonsignificant at $P=0.05$, except as noted.

${ }^{x} \mathrm{~L}=$ Linear.

${ }^{w} \mathrm{~N}$-linear $\times$ spacing interaction significant at $P=0.01$.

Ns,***Nonsignificant or significant at $P=0.05$ or 0.01 , respectively. 
numbers, but with even fewer significant differences (data not presented). Also, hollow stem was negligible in all experiments (data not presented).

Several $\mathrm{N} \times$ spacing interactions were evident for marketable head production in the fall experiments (Table 4). In Fall 1986, average marketable head weight increased linearly with increases in applied $\mathrm{N}$, and heads were heavier at the $30-\mathrm{cm}$ than at the $15-\mathrm{cm}$ spacing. However, the total number of marketable heads responded much more to $\mathrm{N}$ at the $15-\mathrm{cm}$ than at the 30 $\mathrm{cm}$ spacing. As a result, a complex $\mathrm{N}$-cubic $\times$ spacing interaction was evident for total marketable head weight (Table 4). In Fall 1987, with higher rates of applied $\mathrm{N}$ and about normal rainfall, average marketable head weight responded more to $\mathrm{N}$ at the $30-\mathrm{cm}$ than at the $15-\mathrm{cm}$ spacing. Thus, even though $\mathrm{N}$ at the $15-\mathrm{cm}$ spacing increased the total number of marketable heads more than the $30-\mathrm{cm}$ spacing, $\mathrm{N}$ had no effect on total marketable head weights. However, total marketable head weights were higher at the $15-\mathrm{cm}$ than at the $30-\mathrm{cm}$ spacing (Table 4 ).

There were no significant effects of $\mathrm{N}$ on the total number of marketable heads or total marketable head weight in the spring experiments (Table 4). More marketable heads were produced at the $15-\mathrm{cm}$ than at the 30-cm spacing in Spring 1987, but spacing did not affect total marketable head weight. In contrast, spacing did not affect total marketable head production in Spring 1988 , but total marketable head weight was higher at the 30$\mathrm{cm}$ than at the $15-\mathrm{cm}$ spacing. In both cases, the results can be explained by the larger average weights of marketable heads produced at the $30-\mathrm{cm}$ than at the $15-\mathrm{cm}$ spacing (Table 4 ).

Spacing in broccoli can depend on many factors, including whether or not once-over harvesting is desired (Chung, 1982), cultivars used (Cutcliffe, 1975a), and the head size needed for a particular market (Palevitch, 1970; Thompson and Taylor, 1976). However, there are indications that broccoli yields show little increase at populations >10 plants $/ \mathrm{m}^{2}$ (Palevitch, 1970; Thompson and Taylor, 1976; Zink and Akana, 1951). Relatively low plant populations have little effect on broccoli yield, because the reduction in number of plants per hectare largely is offset by the increased head weight per plant (Aldrich et al., 1961). We saw evidence of this when comparing yields from the $30-\mathrm{cm}$ spacing to those from the $15-\mathrm{cm}$ spacing.

While there are many reports of increased broccoli yield in response to increases in applied $\mathrm{N}$, there is disagreement on an optimum rate of applied N. Beverly et al. (1986) found that $\mathrm{N}$ at $140 \mathrm{~kg} \cdot \mathrm{ha}^{-1}$ was sufficient for a $10 \mathrm{t} \cdot \mathrm{ha}^{-1}$ yield of irrigated broccoli. Hipp (1974) obtained a quadratic yield response as $\mathrm{N}$ rates increased from $\mathrm{O}$ to $224 \mathrm{~kg} \cdot \mathrm{ha}^{-1}$. Average plant top weight and average head weight also showed quadratic responses to $\mathrm{N}$ in a study by Letey et al. (1983) using $\mathrm{N}$ rates of 90,180 , and $270 \mathrm{~kg} \cdot \mathrm{ha}^{-1}$. Nitrogen rates of 175 to $250 \mathrm{~kg} \cdot \mathrm{ha}^{-1}$ were recommended by Cutcliffe et al. (1968). Dufault and Waters (1985) suggested that broccoli yields would respond to $\mathrm{N}$ rates $>224$ $\mathrm{kg} \cdot \mathrm{ha}^{-1}$, Greenwood et al. (1980) reported $248 \mathrm{~kg} \cdot \mathrm{ha}^{-1}$ as the optimum amount of $\mathrm{N}$ fertilizer for broccoli. Kowalenko and Hall (1987) obtained yield increases with up to $250 \mathrm{~kg} \mathrm{~N} / \mathrm{ha}$.

Nitrogen had no significant effect on total marketable head weight per hectare in three out of four of our experiments (Table 4). A response was observed only in Fall 1986, when the lowest rates of applied $\mathrm{N}$ were used. The quadratic responses of petiole $\mathrm{N}$ concentration to applied $\mathrm{N}$ in the spring experiments (Table 2) confirmed that there was no benefit from our highest $\mathrm{N}$ rate $\left(280 \mathrm{~kg} \cdot \mathrm{ha}^{-1}\right)$. This result supports the previously cited studies.

Average weights of marketable head consistently were lower at the $15-\mathrm{cm}$ than at the $30-\mathrm{cm}$ spacing (Table 4). Others also have reported decreased individual broccoli head sizes with increased plant populations (Aldrich et al., 1961; Cutcliffe, 1971; Dufault and Waters, 1985; Palevitch, 1970; Salter et al., 1984; Zink and Akana, 1951). Increasing $\mathrm{N}$ usually produced a linear increase in average marketable head weight, especially in the fall at the $30-\mathrm{cm}$ spacing (Table 4). Increased individual head weights in response to applied $\mathrm{N}$ also were obtained by Letey et al. (1983), Dufault and Waters (1985), and Kowalenko and Hall (1987).

Table 4. Yield of broccoli in response to applied $\mathrm{N}$ and within-row spacing.

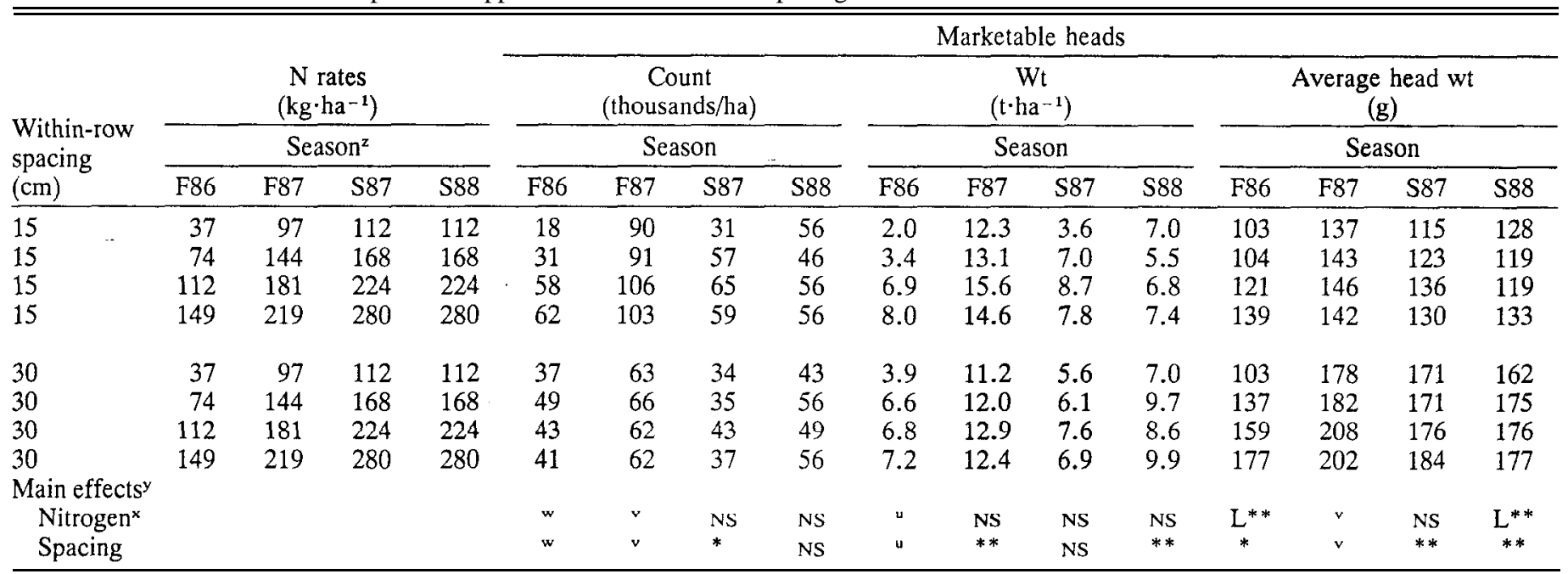

${ }^{\bar{z}}$ F86 = Fall 1986; F87 = Fall 1987; S87 = Spring 1987; S88 = Spring 1988.

${ }^{y}$ All $\mathrm{N} \times$ spacing interactions were nonsignificant at $P=0.05$, except as noted.

${ }^{\mathrm{x}} \mathrm{L}=$ Linear.

"N-linear $\times$ spacing interaction significant at $P=0.01$

N-linear $\times$ spacing interaction significant at $P=0.05$.

${ }^{\mathrm{N}} \mathrm{N}$-cubic $\times$ spacing interaction significant at $P=0.05$.

Ns,$* * *$ Nonsignificant or significant at $P=0.05$ or 0.01 , respectively. 
Table 5. Earliness and percent of field-planted transplants producing marketable heads' of broccoli in response to applied $\mathrm{N}$ and within-row spacing.

\begin{tabular}{|c|c|c|c|c|c|c|c|c|c|c|c|c|}
\hline \multirow{3}{*}{$\begin{array}{l}\text { Within-row } \\
\text { spacing } \\
\text { (cm) }\end{array}$} & \multicolumn{4}{|c|}{$\begin{array}{c}\mathrm{N} \text { rates } \\
\left(\mathrm{kg} \cdot \mathrm{ha}^{-1}\right)\end{array}$} & \multicolumn{4}{|c|}{$\begin{array}{c}\text { Days to } \\
\text { first harvest }\end{array}$} & \multicolumn{4}{|c|}{$\begin{array}{c}\text { Field-planted } \\
\text { transplants producing } \\
\text { marketable heads } \\
(\%)\end{array}$} \\
\hline & \multicolumn{4}{|c|}{ Season ${ }^{2}$} & \multicolumn{4}{|c|}{ Season } & \multicolumn{4}{|c|}{ Season } \\
\hline & F86 & F87 & S87 & $\mathrm{S} 88$ & F86 & F87 & S87 & S88 & F86 & F87 & S87 & S88 \\
\hline $\begin{array}{l}15 \\
15 \\
15 \\
15\end{array}$ & $\begin{array}{r}37 \\
74 \\
112 \\
149\end{array}$ & $\begin{array}{r}97 \\
144 \\
181 \\
219\end{array}$ & $\begin{array}{l}112 \\
168 \\
224 \\
280\end{array}$ & $\begin{array}{l}112 \\
168 \\
224 \\
280\end{array}$ & $\begin{array}{l}76 \\
74 \\
73 \\
73\end{array}$ & $\begin{array}{l}69 \\
68 \\
68 \\
69\end{array}$ & $\begin{array}{l}71 \\
71 \\
70 \\
69\end{array}$ & $\begin{array}{l}67 \\
68 \\
69 \\
67\end{array}$ & $\begin{array}{l}13 \\
21 \\
39 \\
42\end{array}$ & $\begin{array}{l}60 \\
62 \\
72 \\
70\end{array}$ & $\begin{array}{l}22 \\
39 \\
44 \\
40\end{array}$ & $\begin{array}{l}38 \\
31 \\
38 \\
38\end{array}$ \\
\hline $\begin{array}{l}30 \\
30 \\
30 \\
30\end{array}$ & $\begin{array}{r}37 \\
74 \\
112 \\
149\end{array}$ & $\begin{array}{r}97 \\
144 \\
181 \\
219\end{array}$ & $\begin{array}{l}112 \\
168 \\
224 \\
280\end{array}$ & $\begin{array}{l}112 \\
168 \\
224 \\
280\end{array}$ & $\begin{array}{l}73 \\
72 \\
71 \\
72\end{array}$ & $\begin{array}{l}66 \\
66 \\
67 \\
67\end{array}$ & $\begin{array}{l}68 \\
66 \\
67 \\
65\end{array}$ & $\begin{array}{l}67 \\
66 \\
66 \\
66\end{array}$ & $\begin{array}{l}50 \\
64 \\
58 \\
56\end{array}$ & $\begin{array}{l}85 \\
90 \\
83 \\
83\end{array}$ & $\begin{array}{l}44 \\
48 \\
58 \\
52\end{array}$ & $\begin{array}{l}58 \\
75 \\
67 \\
75\end{array}$ \\
\hline $\begin{array}{c}\text { Main effects } \\
\text { Nitrogen } \\
\text { Snacing }\end{array}$ & & & & & $\begin{array}{l}\text { NS } \\
*\end{array}$ & $\begin{array}{l}\text { NS } \\
*\end{array}$ & $\begin{array}{l}v \\
v\end{array}$ & $\begin{array}{l}\text { NS } \\
* *\end{array}$ & $\begin{array}{l}u \\
u\end{array}$ & $\begin{array}{l}\text { NS } \\
* *\end{array}$ & $\begin{array}{l}\text { NS } \\
* *\end{array}$ & $\begin{array}{l}\text { NS } \\
* *\end{array}$ \\
\hline
\end{tabular}

${ }^{2}$ Calculated as number of marketable heads per plot/total number of potential data plants in that plot.

${ }^{y}$ Calculated from date of field-planting.

${ }^{x}$ F86 = Fall 1986; F87 = Fall 1987; S87 = Spring 1987; S88 = Spring 1988.

"Ail $\mathrm{N} \times$ spacing interactions were nonsignificant at $P=0.05$, except as noted.

N-cubic $\times$ spacing interaction significant at $P=0.05$.

${ }^{\text {N}} \mathrm{N}$-linear $\times$ spacing interaction significant at $\mathrm{P}=0.01$

$\mathrm{NS},{ }^{*}, *$ Nonsignificant or significant at $\mathrm{P}=0.05$ or 0.01 , respectively.

The $15-\mathrm{cm}$ spacing resulted in later maturitv than the $30-\mathrm{cm}$ spacing in all experiments; the average delay was 2.3 days (Table 5). Zink and Akana (1951), Aldrich et al. (1961), and Cutcliffe $(1971,1975 a)$ also found delays in maturity as spacing decreased. Nitrogen had little or no effect on days to first harvest, except for an inconsistent effect in Spring 1987 (Table 5). This result is in agreement with Dufault and Waters (1985) and Beverly et al. (1986). In contrast, Hipp (1974) reported increased earliness with increased applied $\mathrm{N}$, while Cutcliffe et al. (1968) reported dealyed maturity with increasing $\mathrm{N}$ rates.

Uniformity of maturity was expressed as the percentage of heads harvested after two harvests. Neither within-row spacing nor applied $\mathrm{N}$ affected the uniformity of maturity in any of the experiments (data not presented), with one exception. In Fall $1987,35 \%$ of the total harvest was completed after two harvests at the $15-\mathrm{cm}$ spacing, compared to $55 \%$ at the $30-\mathrm{cm}$ spacing; the main effect of spacing was significant at $P=0.01$. The overall mean (across all four experiments) was 64\%. There was no obvious-relationship between uniformity of maturity and plant density in studies by Chung (1982) and Salter et al. (1984).

Values for percentage of field-planted transplants producing marketable heads were lower at the $15-\mathrm{cm}$ than at the $30-\mathrm{cm}$ spacing in all experiments (Table 5). Similar findings were reported by Zink and Akana (1951), Cutcliffe (1971), and Thompson and Taylor (1976). Nitrogen affected the percentage of fieldplanted transplants producing marketable heads only in Fall 1986, when the lowest rates of applied $\mathrm{N}$ were used (Table 5).

These studies showed that a close within-row spacing $(15 \mathrm{~cm})$ did not affect the maximum force to shear broccoli stalks and decreased average stalk diameter by only $3 \mathrm{~mm}$, compared to a spacing of $30 \mathrm{~cm}$. Within-row spacings of $<30 \mathrm{~cm}$, which produce plant populations $>7.4$ plants $/ \mathrm{m}^{2}$, may be advantageous. However, a within-row spacing of $15 \mathrm{~cm}$ appeared to be too close, based on higher cull head production, lower average weight of marketable heads, delayed maturity, and greater labor and transplant expenses with a lower percentage of field-planted transplants producing marketable heads than the $30-\mathrm{cm}$ spacing.

Nitrogen did not affect the maximum force to shear broccoli stalks in three out of four experiments and affected stalk diameter only when very low rates (37 and $74 \mathrm{~kg} \cdot \mathrm{ha}^{-1}$ ) were included. Yield of marketable-quality heads often showed no response to rates of applied $\mathrm{N}>112 \mathrm{~kg} \cdot \mathrm{ha}^{-1}$, particularly at the $30-\mathrm{cm}$ spacing. However, there were trends in several variables suggesting possible benefits from slightly higher $\mathrm{N}$ rates (ranging from 144 to $168 \mathrm{~kg} \cdot \mathrm{ha}^{-1}$, under certain conditions. There were no benefits from using a high rate of applied $\mathrm{N}$ (280 $\left.\mathrm{kg} \cdot \mathrm{ha}^{-1}\right)$.

\section{Literature Cited}

Aldrich, T. M., M.J. Snyder, and T.M. Little. 1961. Plant spacing in broccoli. Calif. Agr. 15(12):10-11.

Association of Official Analytical Chemists. 1970. Official methods of analysis. 1lth ed. Washington, D.C.

Beverly, R. B., W.M. Jarrell, and J. Letey, Jr. 1986. A nitrogen and water response surface for sprinkler-irrigated broccoli. Agron. J. 78:91-94.

Chung, B. 1982. Effects of plant density on the maturity and onceover harvest yields of broccoli. J. Hort. Sci. 57:365-372.

Cutcliffe, J.A. 1971. Effects of plant population, nitrogen, and harvest date on yield and maturity of single-harvested broccoli. HortScience 6:482-484.

Cutcliffe, J.A. 1972. Effects of plant spacing and nitrogen on incidence of hollow stem in broccoli. Can. J. Plant Sci. 52:833-834.

Cutcliffe, J.A. 1975a. Effect of plant spacing on single-harvest yields of several broccoli cultivars. HortScience 10:417-419.

Cutcliffe, J.A. 1975b. Cultivar and spacing effects on incidence of hollow stem in broccoli. Can. J. Plant Sci. 55:867-869.

Cutcliffe, J. A., D.C. Munro, and D.C. MacKay. 1968. Effect of nitrogen, phosphorus, potassium, and manure on terminal, lateral, and total yields and maturity of broccoli. Can. J. Plant Sci. 48:439-446.

Dufault, R.J. and L. Waters, Jr. 1985. Interaction of nitrogen fertility 
and plant populations on transplanted broccoli and cauliflower yields. HortScience 20:127-128.

Greenwood, D. J., T.J. Cleaver, M.K. Turner, J. Hunt, K.B. Niendorf, and S.M.H. Loquens. 1980. Comparison of the effects of nitrogen fertilizer on the yield, nitrogen content and quality of 21 different vegetable and agricultural crops. J. Agr. Sci., Cambridge 95:471485.

Hipp, B.W. 1974. Influence of nitrogen and maturity rate on hollow stem in broccoli. HortScience 9:68-69.

Kowalenko, C.G. and J.W. Hall. 1987. Effects of nitrogen applications on direct-seeded broccoli from a single harvest adjusted for maturity. J. Amer. Soc. Hort. Sci. 112:9-13.

Letey, J., W.M. Jarrell, N. Valoras, and R. Beverly. 1983. Fertilizer application and irrigation management of broccoli production and fertilizer use efficiency. Agron. J. 75:502-507.

Massey, P. H., Jr., J.F. Eheart, R.W. Young, and G.E. Mattus. 1962. The effect of soil moisture, plant spacing, and leaf pruning on the yield and quality of broccoli. Proc. Amer. Soc. Hort. Sci. 81:316323.

McElreath, D.L. and G.V. Johnson. 1990. Oklahoma State University soil, water and forage analytic laboratory procedures manual. Pub. AGRON 90-1, Okla. State Univ., Stillwater.

Palevitch, D. 1970. Effects of plant population and pattern on yield of broccoli (Brussica oleracea var. italica) in single harvest. HortScience 5:230-231.

Salter, P. J., D.J. Andrews, and J.M. Akehurst. 1984. The effects of plant density, spatial arrangement and sowing date on yield and head characteristics of a new form of broccoli. J. Hort. Sci. 59:79-85.

Thompson, R. and H. Taylor. 1976. Plant competition and its implications for cultural methods in calabrese. J. Hort. Sci. 51: 147-157. U.S. Department of Agriculture. 1987. Agricultural statistics. U.S. Dept. of Agr., Washington, D.C.

Zink, F.W. and D.A. Akana. 1951. The effect of spacing on the growth of sprouting broccoli. Proc. Amer. Soc. Hort. Sci. 58:160-164. 